\title{
PKM DIDESA DANOWUDU KOTA BITUNG
}

\author{
Diane M. Tengker \\ Universitas Negeri Manado \\ dianetengker@unima.ac.id
}

\begin{abstract}
Abstrak
Pembelajaran menyenangkan artinya pembelajaran yang interaktif dan atraktif, sehingga anak didik dapat memusatkan perhatian terhadap pembelajaran yang sedang dijalaninya. Dalam pemilihan media seorang pendidik diharapakan pandai-pandai memilih dan memilah media yang akan digunakan dalam kegiatan belajar mengajar. Media pembelajaran yang akan digunakan harus menyesuaikan dengan umur siswa, keadaan siswa, situasi lingkunan belajar siswa, kemampuan siswa, dan waktu yang tepat.Tiap jenis media mempunyai karakteristik atau sifat-sifat khas tersendiri. Artinya mempunyai kelebihan dan kekurangan satu terhadap yang lain. Sifat-sifat yang biasanya dipakai untuk menentukan kesesuaian penggunaan atau pemilihan media ialah:

\section{Jangkauan \\ 2. Keluwesan \\ 3. Ketergantungan \\ 4. Atribut.}

Anak didik belajar, 10\% dari apa yang dibaca, 20\% dari apa yang didengar, 30\% dari apa yang dilihat, 50\% dari apa yang dilihat dan didengar, 70\% dari apa yang dikatakan, dan 90\% dari apa yang dikatakan dan dilakukan (Sheal, Peter, 1989). Guru yang aktif adalah guru yang memantau kegiatan belajar anak didik, memberi umpan balik, mengajukan pertanyaan yang menantang, dan memperbanyak gagasan anak didik untuk dapat dimunculkan. Sedangkan anak didik yang aktif adalah mereka yang sering bertanya, mengemukakan pendapat, mempertanyakan gagasan sendiri/orang lain, dan aktif melakukan suatu kegiatan belajar .

Kegiatan pengabdian pada masyarakat dalam bentuk pelatihan penggunaan media pembelajaran yang bervariasi kepada Guru-guru di Guru-guru di Desa Danowudutelah berhasil dilaksanakan dengan baik.

Pelaksanaan pelatihan ini telah mencapai tujuan yang dilaksanakan karena semua peserta dapat menguasai dan membuat media pembelajaran yang bervariasi
\end{abstract}

Kata kunci : Media, Bahasa, Pembelajaran,pelatihan 


\section{PENDAHULUAN}

\section{A. ANALISIS SITUASI}

Guru profesional adalah orang yang terdidik dan terlatih dengan baik serta memiliki pengalaman yang kaya di bidangnya. Yang dimaksud dengan terdidik dan terlatih bukan hanya memilki pendidikan formal tetapi juga harus menguasai berbagai strategi atau teknik dalam KBM serta landasan-landasan kependidikan seperti tercantum dalam kompetensi guru dalarn uraian selanjutnya. Dalam melakukan kewenangan profesionalismenya, guru dituntut memiliki seperangkat kemampuan (kompetensi) yang beraneka ragam. Namun sebelum sampai pada pembahasan kompetensi ada beberapa syarat profesi yang harus dipahami terlebih dahulu. Media adalah sebuah alat yang mempunyai fungsi menyampaikan pesan (Bovee, 1997). Media pembelajaran adalah sebuah alat yang berfungsi untuk menyampaikan pesan pembelajaran. Pembelajaran adalah sebuah proses komunikasi antara pembelajar, pengajar dan bahan ajar. Komunikasi tidak akan berjalan tanpa bantuan sarana penyampai pesan atau media. Guru profesional adalah orang yang memiliki kemampuan dan keahlian khusus dalam bidang keguruan sehingga ia mampu melakukan tugas dan fungsinya sebagai guru secara maksimaI. Dengan kata lain Mengingat tugas guru yang demikian kompleksnya, maka profesi ini memerlukan persyaratan khusus sebagai berikut:1. Menuntut adanya keterampilan yang berdasarkan konsep dan teori ilmu a. pengetahuan yang mendalam 2 . Menekankan pada suatu keahlian dalam bidang tertentu sesuai dengan bidang profesinya. 3.Menuntut tingkat pendidikan keguruan yang memadai. 4. Adanya kepekaan terhadap dampak kemasyarakatan dari pekerjaan yang dilaksanakannya 5. Memungkinkan perkembangan sejalan dengan dinamika kehidupannya. Untuk itulah seorang guru harus mempersiapkan diri sebaik-baiknya untuk memenuhi panggilan tugasnya, baik berupa in-service training (diklat/penataran) maupun pre-service training (pendidikan keguruan secara formal).

Seorang pengajar, perlu membekali dirinya dengan pengetahuan yang baik tentang bidang studi yang harus diajarkannya dan mempersiapkan model pembelajaran yang lebih inovatif, termasuk cara pengajaran, media pengajaran dan lainlain, agar tujuan pembelajaran dapat tercapai. Cara mengajar yang menarik akan membuat siswa tidak bosan, oleh sebab itu pengajar harus pandai memilih media pengajaran yang tepat. Tren pembelajaran yang terkini adalah pembelajaran kontekstual. Belajar secara kontekstual adalah konsep belajar yang membantu guru 
mengaitkan materi pembelajaran dengan situasi dunia nyata peserta didik, dan mendorong peserta didik membuat hubungan antara pengetahuan yang dimilikinya dengan penerapannya dalam kehidupan sehari-hari (Masnur Muslich: 2007).

Media adalah segala sesuatu yang dapat digunakan untuk menyalurkan pesan dari pengirim ke penerima sehingga dapat merangsang pikiran, perasaan, perhatian dan minat serta perhatian peserta didik (Arif Sadimin:2002). Dalam proses pembelajaran, media yang digunakan disebut media pendidikan. Fungsi media memiliki multi makna, baik dilihat secara terbatas maupun secara luas. Bila ada beda pendapat tentang fungsi media ini hal ini disebabkan adanya perbedaan dalam sudut pandang, maksud, dan tujuannya. AECT (Association for Education and Communicatian Technology) dalam Harsoyo (2002) memaknai media sebagai segala bentuk yang dimanfaatkan dalam proses penyaluran informasi.

Sebagai salah satu jalan untuk meningkatkan semangat belajar dan ketertarikan siswa maka perlulah dilakukan perbaikan cara pengajaran dengan memanfaatkan sarana multimedia, komputer, dan berbagai sarana tekhnologi informasi modern, yang telah memberi berbagai kemudahan dalam proses pembelajaran, serta menjadikan mata pelajaran ini lebih real / nyata, berwarna, dan menarik. Kehadiran media elektronik seperti komputer dengan fasilitas internet, ditambah LCD untuk penayangannya, sebagai media belajar merangsang guru untuk lebih bisa memanfaatkanya sebagai sarana penunjang yang menarik.

Dalam berbagai kasus, kualitas sistem pendidikan secara keseluruhan berkaitan dengan kualitas guru (Beeby, 1969). Untuk itu, peningkatan kualitas pendidikan harus dilakukan melalui upaya peningkatan kualitas guru. Secara garis besar, tugas dan tanggung jawab seorang guru adalah mengembangkan kecerdasan yang ada dalam diri setiap anak didiknya. Kecerdasan ini harus dikembangkan agar anak didik dapat tumbuh dan besar menjadi manusia yang cerdas dan siap menghadapi segala tantangan di masa depan. Berhasil atau gagalnya pencapaian tujuan pendidikan tergantung pada proses belajar dan mengajar yang dialami mahasiswa itu disekolah maupun dikeluarga itu sendiri. Belajar merupakan proses dasar dari pada perkembangan hidup manusia. Dengan belajar, manusia melakukan perubahan-perubahan kualitatif individu sehingga tingkah lakunya berkembang.semua aktifitas dan prestasi hidup manusia adalah hasil dari belajar. Belajar merupakan sebuah proses dan melalui proses tersebut individu yang melakukan kegiatan belajar memperoleh pengalaman. Oleh karena itu belajar berlangsung secara aktif dengan 
menggunakan berbagai bentuk perbuatan untuk mencapai suatu tujuan.

\section{Identifikasi Dan Perumusan Masalah}

Penggunaan media pembelajaran merupakan salah satu hal yang akan mendukung keberhasilan siswa dalam menguasai materi pelajaran. Berbagai jenis media pembelajaran berbasis tekhnologi informasi dan komunikasi makin berkembang, mulai dari penggunaan komputer, pemanfaatan jaringan internet, pemutaran film untuk beberapa materi pelajaran, dan salah satunya adalah dengan pemanfaatan program Microsoft office powerpoint dalam penyajian materi pelajaran.

Metode pembelajaran menggunakan computer dapat memberikan pengalaman baru dan menyenangkan baik bagi guru maupun siswa. Selain pembelajaran yang lebih bervariasi anak pun dikenalkan dengan perangkat teknologi dan pada akhirnya mampu meningkatkan / mempermudah pemahaman suatu materi pelajaran oleh siswa. Computer Aided Learning (CAL) adalah sebuah metode pembelajaran yang menggunakan media komputer, dimana dapat menyampaikan pengajaran secara langsung kepada pemakai melalui cara berinteraksi dalam mata pelajaran yang telah di kemas dalam bentuk perangkat lunak. Didalam CAL, perangkat lunak tersebut akan mengontrol beberapa proses, yaitu : menyajikan materi kepada pemakai untuk dibaca atau di dengar, memberi petunjuk pembelajaran dan latihan-latihan yang berhubungan dengan materi yang dipelajari, serta memberikan pemecahan dari pertanyaan yang disajikan. CAL (Computer Aided Learning) memiliki 4 konsep, konsep itu antara lain : (1) Latih (Drill) dan Praktek (Practice), Penjelasan (Tutorial), (3) Simulasi Permainan

\section{TARGET DAN LUARAN}

\section{A. Target :}

Berdasarkan latar belakang pemikiran dan konteks permasalahan yang ada, maka pelaksanaan pelatihan ini bertujuan, terutama untuk menghasilkan pengajar yang berpengetahuan, berkemampuan dan memiliki keterampilan; mengajar yang baik, yang mudah diserap oleh para pembelajar. Menerapkan model-model pengajaran yang koopratif yang mudah diserap oleh pembelajar adalah upaya pengajar untuk mencapai tujuan yang diharapkan yaitu dapat menguasai empat keterampilan berbahasa yakni; keterampilan berbicara, membaca, menulis, menyimak.

\section{B. Luaran}

Luaran yang diharapkan melalui pelaksanaan kegiatan pengabdian pada masyarakat ini adalah sebagai berikut:

1. Peningkatan kualitas sumber daya manusia yakni Guru-guru di Desa Danowudu 
2. Melalui kegiatan ini diharapkan para Guru-guru di Desa Danowudu dapat memiliki pengetahuan yang positif dalam rangka upaya peningkatan kecakapan profesional dan pedagogik .

\section{METODE}

\section{A. Metode Pelaksanaan}

Tujuan kegiatan yang ingin dicapai melalui kegiatan pengabdian ini adalah untuk meningkatkan pengetahuan upaya peningkatan kualitas guru. Secara garis besar, tugas dan tanggung jawab seorang guru adalah mengembangkan kecerdasan yang ada dalam diri setiap anak didiknya. Kecerdasan ini harus dikembangkan agar anak didik dapat tumbuh dan besar menjadi manusia yang cerdas dan siap menghadapi segala tantangan di masa depan. Berhasil atau gagalnya pencapaian tujuan pendidikan tergantung pada proses belajar dan mengajar yang dialami mahasiswa itu disekolah maupun dikeluarga itu sendiri. Belajar merupakan proses dasar dari pada perkembangan hidup manusia. Dengan belajar, manusia melakukan perubahan-perubahan kualitatif individu sehingga tingkah lakunya berkembang.semua aktifitas dan prestasi hidup manusia adalah hasil dari belajar. Belajar merupakan sebuah proses dan melalui proses tersebut individu yang melakukan kegiatan belajar memperoleh pengalaman. Oleh karena itu belajar berlangsung secara aktif dengan menggunakan berbagai bentuk perbuatan untuk mencapai suatu tujuan.

Dimyati dan Mudjiono ( 2002 ; 3) mengemukakan bahawa keberhasilan suatu proses belajar mengajar dinilai dari hasil belajar anak didik. Hasil Belajar adalah hasil dari suatu interaksi tindak belajar dan mengajar.. Dengan kata lain pemilihan metode serta media yang tepat dalam pembelajaran turut menentukan keberhasilan proses belajar mengajar, dan keefektifan dalam memilih media pembelajaran yang sesuai pula ikut menentukan keberhasilan proses belajar mengajar.

Media pembelajaran secara umum adalah alat bantu proses belajar mengajar. Segala sesuatu yang dapat dipergunakan untuk merangsang pikiran, perasaan, perhatian dan kemampuan atau keterampilan pembelajar sehingga dapat mendorong terjadinya proses belajar.

Dengan adanya kegiatan pelatihan ini diharapkan dapat memberikan tambahan pengetahuan dan informasi kepada para guru-guru untuk meningkatkan kualitas dalam pengajaran karena pembelajaran dengan multimedia power point ini merupakan solusi bagi beragam masalah pendidikan.

\section{B. Prosedur Pelaksanaan}

Model pembelajaran inovatif ini juga memeri manfaat khusus bagi pengajar, karena dengan menggunakan model 
pembelajaran ini, Cara mengajar yang menarik akan membuat Ibu-ibu tidak bosan, oleh sebab itu pengajar harus pandai memilih media pengajaran yang tepat. Sebab penggunaan media pengajaran yang tepat memegang peranan penting sebagai alat yang dapat mendorong minat belajar serta dapat memberikan stimulus pada indra peserta didik. Menurut Ali (2004:53), "Media pembelajaran diartikan sebagai segala sesuatu yang dapat digunakan untuk menyalurkan pesan (message), menstimulasi pikiran, perasaan, perhatian dan kemauan siswa sehingga dapat membantu kelancaran, efektivitas dan efisiensi pembelajaran".

\section{HASIL DAN PEMBAHASAN}

Kegiatan ini dilaksanakan pada tanggal 7-8 Juni 2019 dan diikuti oleh seluruh Guru-guru desa Danowudu. Tiap jenis media mempunyai karakteristik atau sifat-sifat khas tersendiri. Artinya mempunyai kelebihan dan kekurangan satu terhadap yang lain.Media Pembelajaran mempunyai Tujuan dan Manfaat yaitu.Dalam pemilihan media seorang pendidik diharapakan pandai-pandai memilih dan memilah media yang akan digunakan dalam kegiatan belajar mengajar. Media pembelajaran yang akan digunakan harus menyesuaikan dengan umur siswa, keadaan siswa, situasi lingkunan belajar siswa, kemampuan siswa, dan waktu yang tepat.

\section{MATERI YANG DIBERIKAN:}

\section{Fungsi dan Manfaat Media Pembelajaran}

Hamalik (dalam Arsyad, 2011:15) menjelaskan bahwa pemakaian media pembelajaran dalam proses belajar mengajar dapat membangkitkan keinginan dan minat yang baru, membangkitkan motivasi dan rangsangan kegiatan belajar, dan bahkan membawa pengaruh psikologis terhadap siswa. Penggunaan media pembelajaran pada tahap orientasi pembelajaran akan sangat membantu kefektivan proses pembelajaran dan penyampaian pesan dan isi pelajaran pada saat itu. Selain membangkitkan motivasi dan minat siswa, media pembelajaran juga dapat membantu mahasiswa meningkatkan pemahaman, menyajikan data dengan menarik dan terpercaya, memudahkan penafsiran data, dan memadatkan informasi.

Levie dan Lentz (dalam Arsyad, 2011:16) mengemukakan empat fungsi media pembelajaran, khususnya media visual yaitu, (1) fungsi atensi, merupakan inti, yaitu menarik dan mengarahkan perhatian mahasiswa untuk berkosentarasi kepada isi pelajaran yang berkaitan dengan makna viasual yang ditampilkan atau menyertai teks materi pelajaran. (2) fungsi afektif, media visual dapat terlihat dari 
tingkat kenikmatan mahasiswa ketika belajar atau membaca teks yang bergambar. Gambara atau lambang visual dapat menggugah emosi dan sikap siswa, misalnya informasi yang menyangkut masalah sosial atau ras. (3) fungsi kognitif, media visual terlihat dari temuan-temuan penelitian yang mengungkapkan lambang visual atau gambar memperlancar pencapaian tujuan untuk memahami dan mengingat informasi atau pesan yang terkandung dalam gambar. (4) fungsi kompensatoris, media pembelajaran terlihat dari hasil penelitian bahwa media visual yang memberikan konteks untuk memahami teks membantu mahasiswa yang lemah dalam membaca untuk mengorganisasikan informasi dalam teks dan mengingatnya kembali. Dengan kata lain, media pembelajaran berfungsi untuk mengakomodasikan mahasiswa yang lemah dan lambat menerima dan memahami isi pelajaran yang disajikan dengan teks atau disajikan secara verbal.

Berbagai manfaat media pembelajaran telah dibahas oleh banyak ahli. Menurut Kemp dan Dayton (dalam Arsyad, 2011:21), meskipun telah lama disadari bahwa banyak keuntungan media pembelajaran, penerimaannya serta pengintegrasiannya kedalam programprogram pengajaran berjalan amat lambat. Mereka mengemukakan beberapa hasil penelitian yang menunjukan dampak dari penggunaan media sebagai bagian integral pembelajaran di kelas atau sebagai cara utama pembelajaran langsung sebagai berikut :

1. Penyampaian pelajaran menjadi lebih baku. Setiap pelajar yang melihat atau mendengar penyajian melalui media menerima pesan yang sama. Meskipun para guru menafsirkan isi pelajaran dengan cara yang berbeda-beda, dengan penggunaan media ragam hasil tafsiran itu dapat dikurangi sehingga ragam hasil tafsiran itu dapat disampaikan kepada mahasiswa sebagai landasan untuk pengkajian, latihan dan aplikasi lebih lanjut.

2. Pembelajaran bisa lebih menarik. Media dapat diasosiasikan sebagai penarik perhatian dan membuat mahasiswa tetap terjaga dan memperhatikan.

3. Pembelajaran menjadi lebih interaktif dengan diterapkannya teori belajar dan prinsip-prinsp psikologis yang diterima dalam hal partisipasi siswa, umpan balik, dan penguatan.

4. Lama waktu pembelajaran yang diperlukan dapat dipersingkat karena kebanyakan media hanya memerlukan waktu singkat untuk mengantarkan pesan-pesan dan isi pelajaran dalam jumlah yang cukup banyak dan kemungkinannya dapat diserap oleh siswa. 
5. Sikap positif mahasiswa terhadap apa yang mereka pelajari dan terhadap proses belajar dapat ditingkatkan.

6. Peran guru dapat verubah kearah lebih positif, beban guru untuk penjelasan yang berulang-ulang mengenai isi pelajaran dapat dikurangi bahkan dihilangkan sehingga ia dapat memusatkan perhatian kepada aspek penting lain dalam proses belajar mengajar, misalnya sebagai konsultan atau penasehat siswa.

Manfaat Media Pembelajaran Arsyad ( 1996

:15) mengemukakan bahwa fungsi utama media pendidikan atau media pembelajaran adalah sebagai alat bantu mengajar yang turut mempengaruhi iklim, kondisi dan lingkungan belajar yang ditata dan diciptakan oleh guru. Sanjaya (200 : 167), media pembelajaran memiliki fungsi dan peran untuk :

1. Menangkap suatu objek atau peristiwa - peristiwa tertentu.

2. Memanipulasi keadaan, peristiwa atau objek tertentu.

3. Menambah gairah dan motivasi

Metode yang digunakan dalam kegiatan penyuluhan yang dilaksanakan relevan dengan pokok permasalahan yang disesuaikan dengan tujuan yang ingin dicapai adalah yaitu metode presentasi, tanya jawab, demonstrasi dan pemberian tugas.

Sebelum kita gunakan, media harus kita pilih secara cermat. Memilih media yang terbaik untuk tujuan pembelajaran bukanlah pekerjaan yang mudah. Pemilihan itu rumit dan sulit, karena harus mempertimbangkan berbagai faktor.

1. Model pemilihan media

Anderson (1976) mengemukakan adanya dua pendekatan/model dalam proses pemilihan media pembelajaran, yaitu: model pemilihan tertutup dan model pemilihan terbuka. Pemilihan tertutup terjadi apabila alternatif media telah ditentukan "dari atas" (misalnya oleh Dinas Pendidikan), sehingga mau tidak mau jenis media itulah yang harus dipakai. Kalau toh kita memilih, maka yang kita lakukan lebih banyak ke arah pemilihan topik/pokok bahasan mana yang cocok untuk dimediakan pada jenis tertentu. Misalnya saja, telah ditetapkan bahwa media yang digunakan adalah media audio. Dalam situasi damikian, bukanlah mempertanyakan mengapa media audio yang digunakan, dan bukan media lain? Jadi yang harus kita lakukan adalah memilih topik-topik apa saja yang tepat untuk disajikan melalui media audio. Untuk model pemilihan terbuka, lebih rumit lagi.

Model pemilihan terbuka merupakan kebalikan dari pemilihan tertutup. Artinya, kita masih bebas memilih jenis media apa saja yang sesuai dengan kebutuhan kita. Alternatif media masih terbuka luas. Proses pemilihan terbuka lebih luwes sifatnya karena benar-benar kita sesuaikan dengan kebutuhan dan kondisi yang ada. Namun 
proses pemilihan terbuka ini menuntut kemampuan dan keterampilan guru untuk melakukan proses pemilihan. Seorang guru kadang bisa melakukan pemilihan media dengan mengkombinasikan antara pemilihan terbuka dengan pemilihan tertutup.

\section{Mengapa perlu pemilihan media?}

Media pada hakekatnya merupakan salah satu komponen sistem pembelajaran. Sebagai komponen, media hendaknya merupakan bagian integral dan harus sesuai dengan proses pembelajaran secara menyeluruh. Akhir dari pemilihan media adalah penggunaaan media tersebut dalam kegiatan pembelajaran, sehingga memungkinkan siswa dapat berinteraksi dengan media yang kita pilih.

Apabila kita telah menentukan alternatif media yang akan kita gunakan dalam pembelajaran, maka pertanyaan berikutnya adalah sudah tersediakah media tersebut di sekolah atau di pasaran? Jika sudah tersedia, maka kita tinggal meminjam atau membelinya saja. Itupun jika media yang ada memang sesuai dengan tujuan pembelajaran yang telah kita rencanakan, dan terjangkau harganya. Jika media yang kita butuhkan temyata belum tersedia, mau tak mau kita harus membuat sendiri program media sesuai keperluan tersebut.

Jadi, pemilihan media itu perlu kita lakukan agar kita dapat menentukan media yang terbaik, tepat dan sesuai dengan kebutuhan dan kondisi sasaran didik. Untuk itu, pemilihan jenis media harus dilakukan dengan prosedur yang benar, karena begitu banyak jenis media dengan berbagai kelebihan dan kelemahan masing-masing.

\section{Hakikat Belajar dan Pembelajaran}

Pengajaran merupakan suatu kegiatan atau upaya membantu para siswa mengembangkan kemampuan, pengetahuan, dan keterampilan dalam suatu bidang tertentu, Ibrahim dan Syaodih (1992:2) kegiatan pengajaran tidak sesederhana membeli pakaian. Walaupun tidak sekompleks membangun sebuah kota, tetapi kegiatan ini membutuhkan perencanaan yang seksama dan dibuat secara tertulis.

Dengan lajunya perkembangan dewasa ini khususnya dalkam bidang pendidikan, telah banyak ahli yang mengungkapkan tentang teori belajar.Para ahli pendidikan telah berusaha merumuskan definisi tentang belajar dilihat dari berbagai segi.Berikut ini dikemukakan tentang beberapa pendapat para ahli mengenai pengertian belajar itu.

Para ahli mengenai teori belajar modern menemukakan dan merumuskan pengertian belajar sebagai berikut, belajar adalah suatu bentuk perubahan dalam diri seseorang yang dinyatakan dalam cara-cara bertingkah laku yang baru berkat pengalaman dan latihan (Hamalik, 1982:28).Tingkah laku yang baru itu misalnya dari tidak tahu menjadi tahu, timbulnya pengertianpengertian baru, perubahan dalam sikap, kebiasaan-kebiasaan, keterampilan, 
kesanggupan menghargai, perkembangan sifat-sifat sosial emosional, dan pertumbuhan jasmani.

\section{KESIMPULAN DAN SARAN}

\section{Kesimpulan}

Pembelajaran menyenangkan

artinya pembelajaran yang interaktif dan atraktif, sehingga anak didik dapat memusatkan perhatian terhadap pembelajaran yang sedang dijalaninya. Dalam pemilihan media seorang pendidik diharapakan pandai-pandai memilih dan memilah media yang akan digunakan dalam kegiatan belajar mengajar. Media pembelajaran yang akan digunakan harus menyesuaikan dengan umur siswa, keadaan siswa, situasi lingkunan belajar siswa, kemampuan siswa, dan waktu yang tepat.Tiap jenis media mempunyai karakteristik atau sifat-sifat khas tersendiri. Artinya mempunyai kelebihan dan kekurangan satu terhadap yang lai. Sifatsifat yang biasanya dipakai untuk menentukan kesesuaian penggunaan atau pemilihan media ialah:Jangkauan, Keluwesan, Ketergantungan dan Atribut. Kegiatan pengabdian pada masyarakat dalam bentuk pelatihan penggunaan media pembelajaran yang bervariasi kepada Guru-guru di Guru-guru di Desa Danowudutelah berhasil dilaksanakan dengan baik. Pelaksanaan pelatihan ini telah mencapai tujuan yang dilaksanakan karena semua peserta dapat menguasai dan membuat media pembelajaran yang bervariasi

\section{Saran}

Melihat Apabila capaian nilai > 75\% dari tujuan yang ditetapkan, maka tujuan dinyatakan berhasil. keberhasilan yang diperoleh serta antusiasnya peserta dalam kegiatan pengabdian pada masyarakat dalam bentuk pelatihan berupa kusus singkat seperti ini sangat bagus dan positif bagi pengembangan profesionalitas guru. Penulis merasa perlu ditindak lanjuti pada lokasi yang sama maupun lokasi yang lain dengan topic/materi yang berbeda, mengapa dikatakan demikian karena hal ini dapat meningkatkan rasa percaya diri terutama bagi para guru sehingga menjadi guru yang profesional dalam mengajar di depan kelas.

\section{KEPUSTAKAAN}

Ahmadi Abu dan Supriyono Widodo. Psikologi Belajar. Jakarta: Rineka Cipta, 2004

Ahmadi, Mukhsin. 1990. Strategi Belajar Mengajar Keterampilan Berbahasa dan Apresiasi Sastra. Malang : YA3 Malang. Hartanto, B., \& Wijaya, 2004. F., The Magic of Flash MX 2004, Jakarta: PT. Elex Media Komputindo

Jepri, Mohammad, 2002. Membuat Games dengan Flash MX, Jakarta: PT. Elex Media Komputindo 
Jurnal ABDIMAS, Vol. 12, No. 2, Agustus 2019

ISSN: 1979-0953 | e-ISSN: 2598-6066

Sadewa, Yoel, 2004 Bahasa Jepang Yang

Mudah Yasahii Nihongo, Media Abadi,

Yogyakarta

Zeembry. $\quad 2004.123 \quad$ Tip\&Trik

ActionScript Flash MX Jakarta: PT. Elex

Media Komputindo
Rey, Chrissy, 2001. Macromedia

Flash Training From The Source, Macromedia Press, Berkeley.

Widodo, Edi. 2006. Multimedia dan Pembelajaran Bahasa. Bandung 
Jurnal ABDIMAS, Vol. 12, No. 2, Agustus 2019

ISSN: 1979-0953 | e-ISSN: 2598-6066 